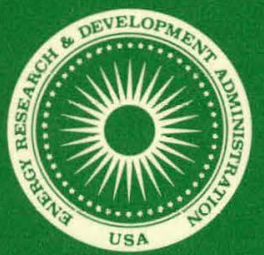

\title{
RESIDENTIAL ENERGY CONSERVATION STRATEGIES
}

Eric Hirst

\section{OAK RIDGE NATIONAL LABORATORY}




\section{DISCLAIMER}

This report was prepared as an account of work sponsored by an agency of the United States Government. Neither the United States Government nor any agency Thereof, nor any of their employees, makes any warranty, express or implied, or assumes any legal liability or responsibility for the accuracy, completeness, or usefulness of any information, apparatus, product, or process disclosed, or represents that its use would not infringe privately owned rights. Reference herein to any specific commercial product, process, or service by trade name, trademark, manufacturer, or otherwise does not necessarily constitute or imply its endorsement, recommendation, or favoring by the United States Government or any agency thereof. The views and opinions of authors expressed herein do not necessarily state or reflect those of the United States Government or any agency thereof. 


\section{DISCLAIMER}

Portions of this document may be illegible in electronic image products. Images are produced from the best available original document. 
Printed in the United States of America: Available from National Technical Information Service

U.S. Department of Commerce

5285 Port Royal Road, Springfield, Virginia 22161

Price: Printed Copy $\$ 4.00$; Microfiche $\$ 2.25$

This report was prepared as an account of work sponsored by the United States Government. Neither the United States nor the Energy Research and Development Administration/United States Nuclear Regulatory Commission, nor any of their employees, nor any of their contractors, subcontractors, or their employees, makes any warranty, express or implied, or assumes any legal liability or responsibility for the accuracy, completeness or usefulness of any information, apparatus, product or process disclosed, or represents that its use would not infringe privately owned rights 
ORNL/CON-2

Contract No. W-7405-eng-26

ENERGY DIVISION

RESIDENTIAL ENERGY CONSERVATION STRATEGIES

Eric Hirst

Date Published: September 1976

Work supported by the Federal Energy Administration and the Energy Research and Development Administration

OAK RIDGE NATIONAL - LABORATORY

Uak Kidge, l'ennessee 3/830

operated by

UNIÜN CARBIDE CORPOORATIONN

for the

ENERGY RESEARCH AND DEVELOPMENT ADMINISTRATION

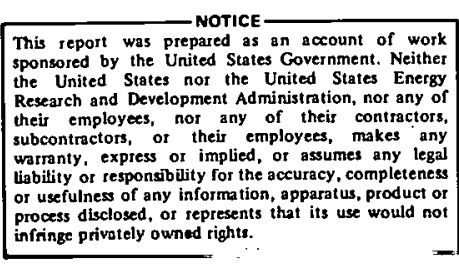

This report was prepared as an account of work sponsored by the United States Government. Neither Research and Development Administration, not any of their employees, nor any of their contractors. warranty, express or implied, or assumes any legal tiabily use rut responsing infringe privotely owned rights. 
THIS PAGE

\section{WAS INTENTIONALLY LEFT BLANK}




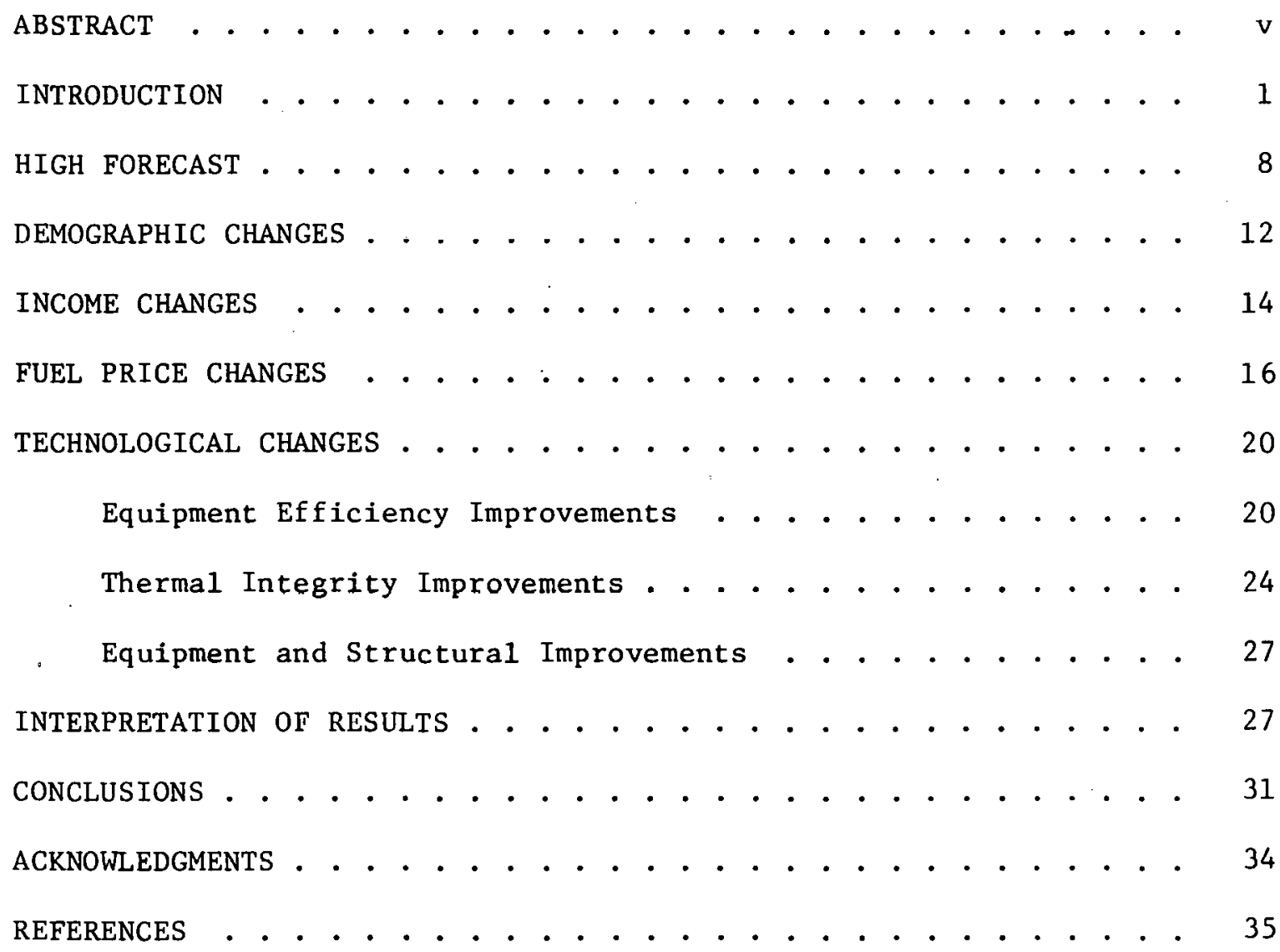


THIS PAGE

\section{WAS INTENTIONALLY LEFT BLANK}




\section{ABSTRACT}

An engineering-economic model of residential energy use is used to evaluate the energy impacts from 1975 to 2000 of changes in: household formation, housing choices, per capita income, fuel prices, equipment efficiencies, and thermal integrities of new and existing residential buildings. Twelve cases are run with the computer model to determine the impacts on energy use of each factor.

These runs suggest the following:

1. Residential energy use will grow more slowly during the fourth quarter of this Century than during the third quarter because of slower growth in population and household formation, changes in fuel price trends, and near saturation of equipment ownership for the major residential energy end uses. Our highest forecast shows a growth of $2.5 \% /$ year, compared with a growth of $3.6 \% /$ year from 1950-1975.

2. The high forecast discussed above is not a likely forecast because it assumes that fuel prices will remain constant at their 1975 values, that household formation will increase rapidly, and that the 1960-70 trend in housing choices (away from single-family units) ., will not continue. More realistic assumptions include slower growth in household formation, rising fuel prices, and a continuation of the 1960-70 trend in housing choices. Under these "business as usual" assumptions, energy use grows at $1.5 \%$ /year. This suggests that energy use will grow at half its historical rate if no new government programs and policies are implemented. Thus a great deal of energy will be "conserved" because of projected changes in demographic conditions and increases in fuel prices.

3. Implementation of energy conservation programs to raise energy prices, increase efficiency of new household equipment, and improve thermal integrity of both new and existing housing units can have significant energy impacts. A vigorous conservation program might yleld an average annual growth rate of $0.4 \%$ between 1975 and 2000 , with an energy use in 2000 only $10 \%$ higher than 1975 energy use. Implementation of such programs would reduce energy use in 2000 from the business as usual case by almost 25\%; the reduction relative to the h1gh case is $40 \%$. 


\section{INTRODUCTION}

Between the end of World War II and the early 1970's, residential energy use grew steadily and rapidly because of growth in population, households, and income; declines in retail fuel prices; and the introduction of new household energy-using devices. Responses to these demographic, economic, and technological changes included: growth in ownership of energy-intensive household equipment (e.g., food freezers, air conditioners), shifts from small energy-efficient devices to larger less efficient units (e.g., replacement. of small manual defrost refrigerators with large automatic defrost models that consume $50-100 \%$ more electricity), and increasing household use of equipment (e.g., taking longer hot showers, leaving lights on, setting thermostats higher in the winter). The net result of these changes was an average annual growth rate in household energy use of $3.6 \%$ between 1950 and 1975 , nearly double the growth rate in household formation $(2.0 \%), 1$ as shown in Fig. 1.*

During the past few years, however, a number of forces have emerged that may significantly alter these historical trends. As shown in Fig. 2, residential fuel prices ${ }^{\dagger}$ began to increase around 1970, after two decades of declines. ${ }^{2}$ Because of these increases in fuel prices,

\footnotetext{
* For those who prefer British units, 1 Btu $=1055 \mathrm{~J}$. Electricity use figures are in terms of primary energy; that is they include losses in generation, transmission, and distribution. Figures for gas and oil, however, do not include losses associated with refining and transportation.

† Fuel prices are deflated by the Consumer Price Index to remove the effects of inflation.
} 


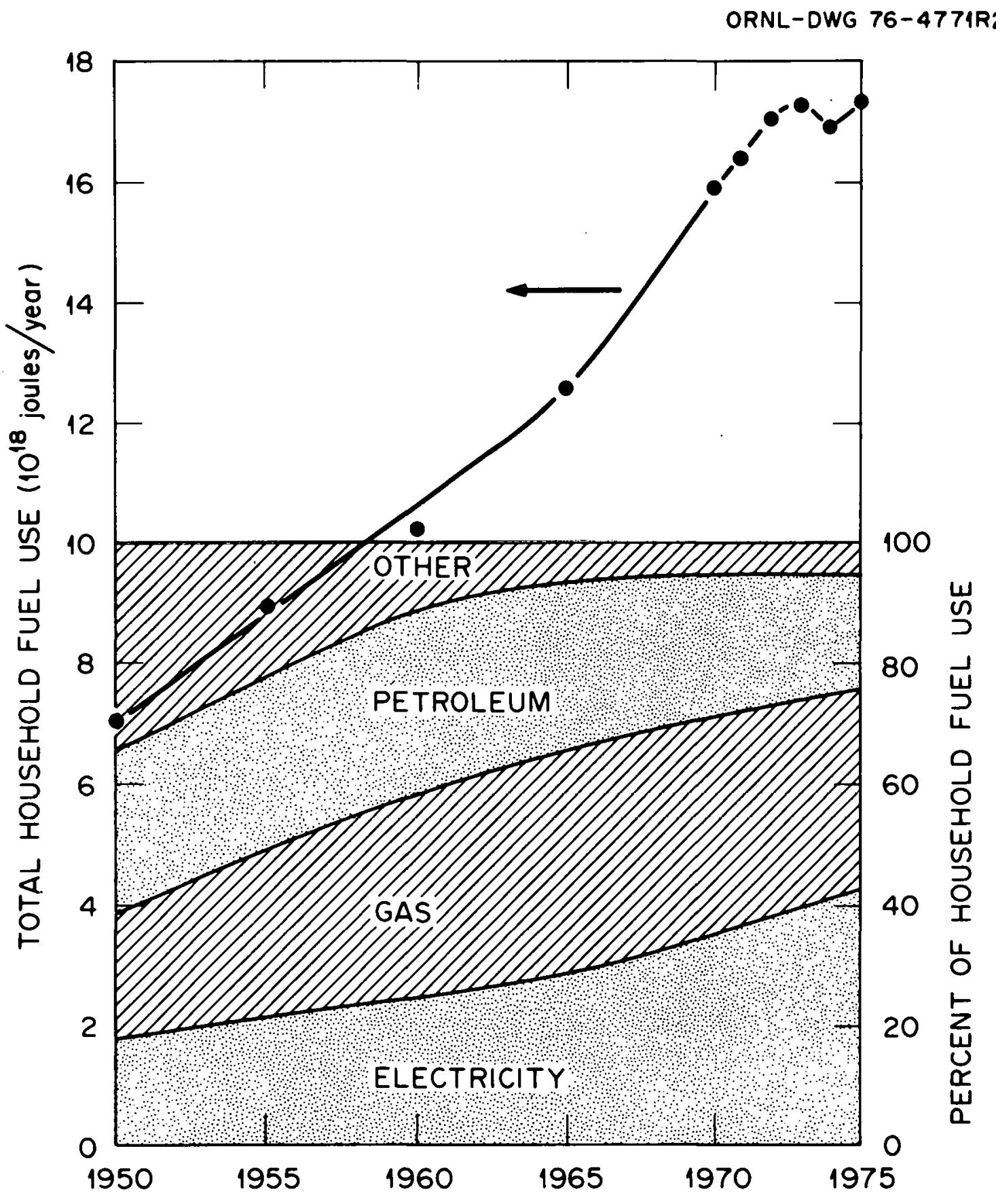

Fig. 1. Household fuel use: 1950-1975. 


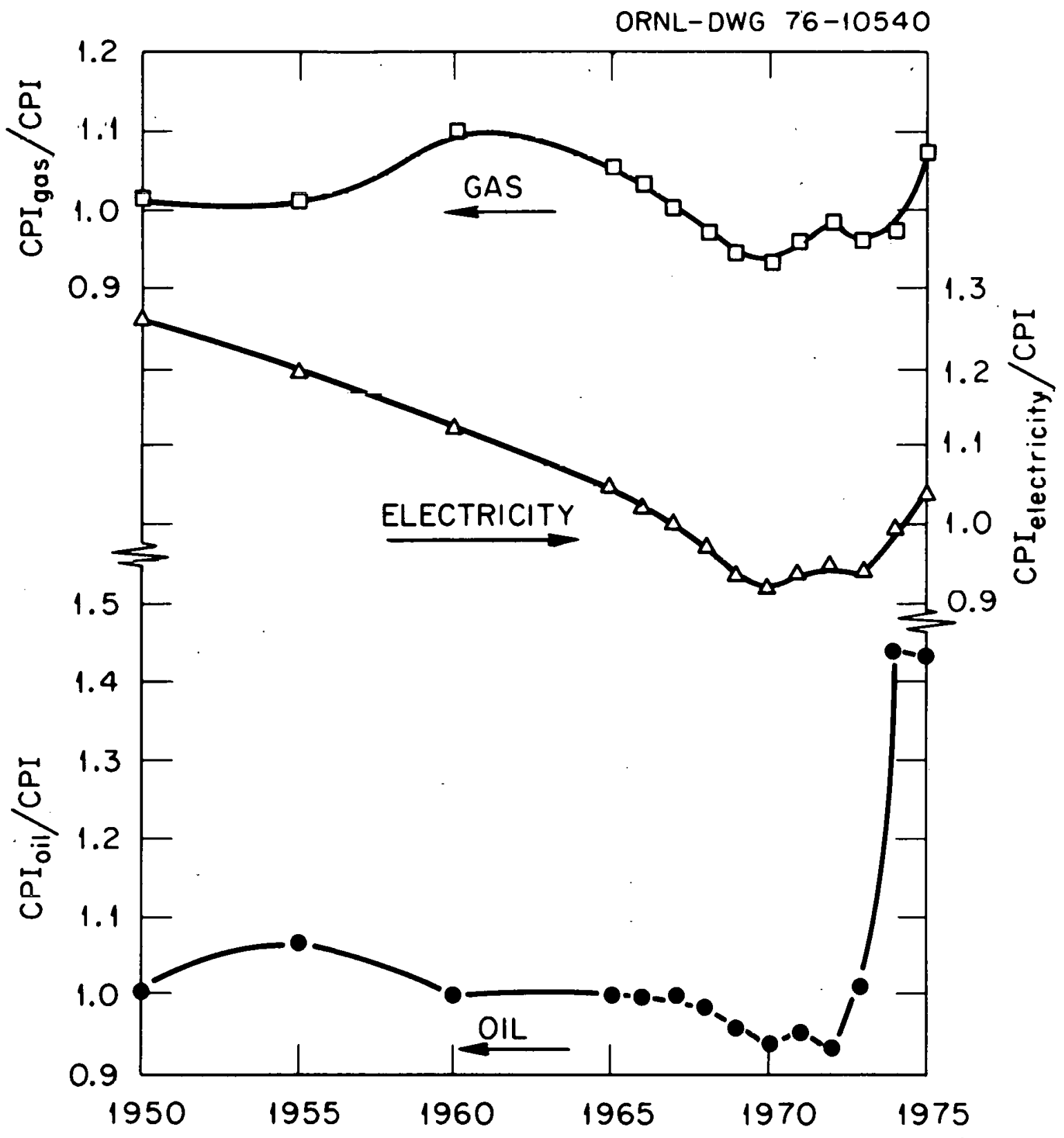

Fig. 2. Trends in retail fuel prices for electricity, gas, and oil. 
personal consumption expenditures on household fuels rose $27 \%$ between 1970 and 1974.

In addition to the economic force of rising prices, a number of institutional changes are underway or under serious consideration. The Federal Energy Administration, created in July 1974, has an Office of Conservation and Environment that develops and implements federal energy conservation policies and programs. The Energy Research and Development Administration, created in January 1975, has an Office of Conservation that manages federal RD\&D programs to develop and commercialize new energy conservation technologies.

The recent federal Energy Policy and Conservation Act (PL 94-163) ${ }^{3}$ requires the FEA to establish voluntary residential equipment and appliance efficiency targets so that the aggregate efficiency of appliances sold in 1980 exceeds the aggregate efficiency for 1972 by at least $20 \%$. The Act also requires that labels be affixed to household appliances showing their energy efficiencies and operating costs.

Legislation establishing a program to develop and implement building energy performance standards is being considered in both Houses of Congress. The American Society of Heating, Refrigerating, and AirConditioning Engineers developed a set of thermal standards for new buildings (ASHRAE 90-75).4 Implementation of these standards would substantially reduce space heating and air conditioning requirements for new housing units with little or no increase in initial costs.

A number of issues related to energy prices - natural gas deregulation, oil price decontrol, and electricity rate reform - are hotly debated although unresolved. 
Table 1 shows several energy conservation measures (actions to reduce household energy growth) and policies to implement these measures. The first three measures - household growth, housing choices, and income growth - are generally considered outside the realm of energy policy. Nevertheless, we later evaluate the residential energy consequences of changes in these demographic and economic forces.

Table 1. Residential Energy Conservation Measures and Policies ${ }^{a}$

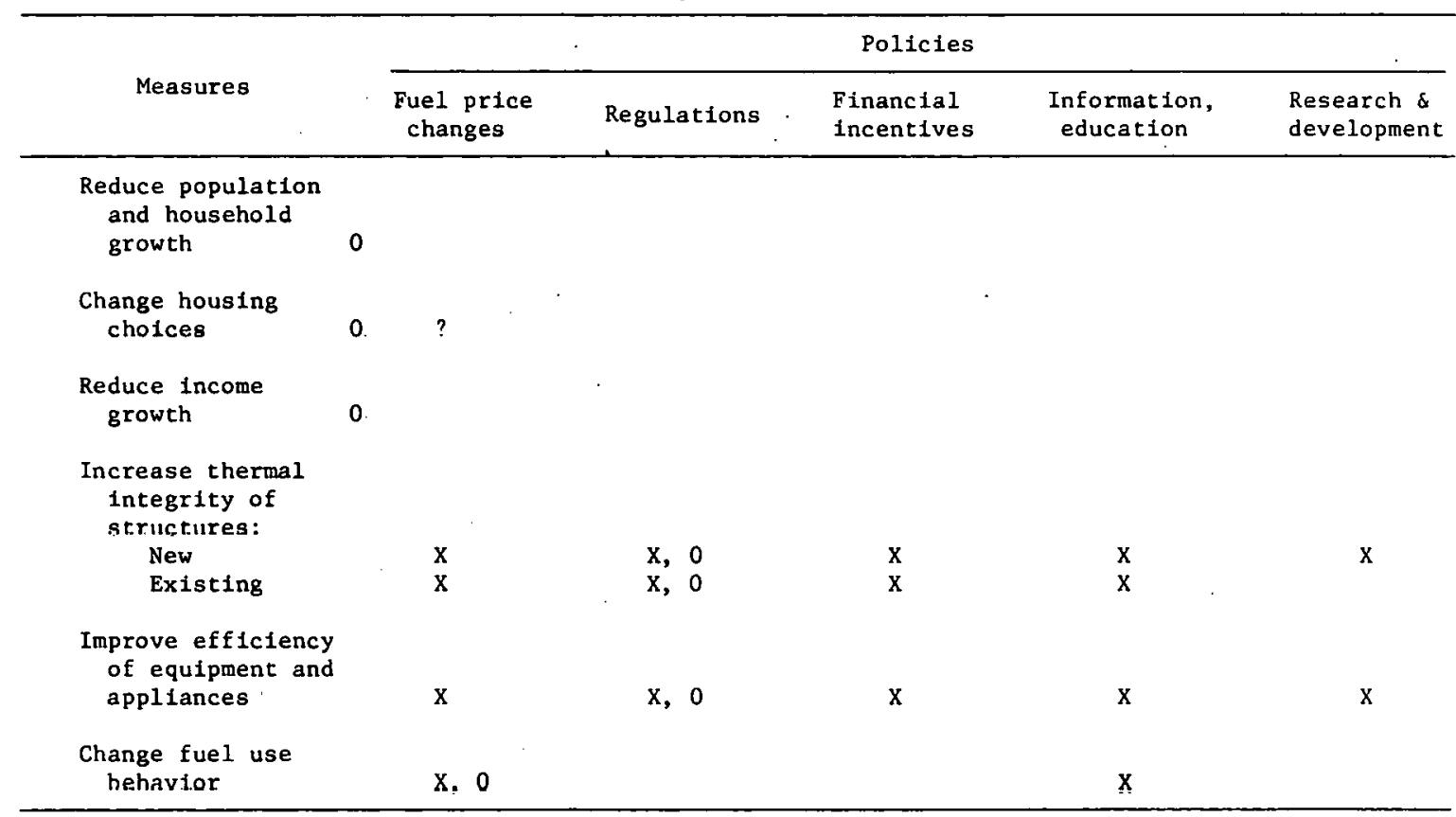

$a_{\mathrm{X}}$ - indicates those policies that can Induce adoption of conservation measure shown.

0 - Indicates those measures and policies evaluated in this report.

Improvements in technical efficiencies for household equipment and structures can be induced by a number of policies, as shown in Table 1:

fuel price increases, regulations, financial incentives and disincentives, information and education, and research and development.

Changes in household behavior have two aspects. One deals with the day-to-day operation of given stocks of equipment and structures. These 
changes in equipment use (thermostat settings, furnace maintenance, number of refrigerator door openings, etc.) can be influenced by changes in fuel prices and information on the energy and dollar impacts of different equipment usage patterns. The second aspect of household behavior deals with choices made when new equipment and residences are purchased. At issue here is the tradeoff between efficiency improvements . (reduced operating costs) and higher initial costs.

In this report we use a detailed computer model of residential energy use developed at ORNL to evaluate the energy impacts of various energy conservation strategies. The model, details of which are in ref. 1, simulates household energy use at the national level for four fuels, six end uses, and three housing types. Each of these fuel use components is computed on an annual basis in response to changes in: stocks of occupied housing units and new residential construction, equipment ownership by fuel and end use, thermal integrity of housing units, average unit energy requirements for each type of residential equipment, and usage factors that reflect household behavior. Thus the model is sensitive to the major demographic, economic, and technological determinants of household fuel use.

The model is used to evaluate the energy impacts between 1975 and 2000 of changes in: household formation, housing choices, incomes, fuel. prices, efficiency of new equipment, efficiency of new structures, and efficiency of existing structures. We start with a set of input boundary conditions to the model that produces a "high" forecast of residential fuel use, as close to historical trends as is reasonably possible. We then postulate a number of changes - reduced household growth, shifts in 
housing choices, slower income growth, increases in fuel prices - to yield a "business-as-usual" forecast. Next we adjust the boundary conditions towards higher fuel prices, improvements in thermal.integrity of new and existing structures, and increases in equipment efficiency. This yields "low" forecasts due to implementation of these conservation strategies. These changes in boundary conditions are applied sequentially so that the influence of each change on household fuel uses can be isolated; interactions among these strategies are also evaluated.

The remainder of this report discusses and compares these forecasts and offers conclusions on the relative energy savings of different government programs and policies. Table 2 lists the 12 sets of boundary conditions used to drive the simulation model and briefly summarizes the energy impacts of these exogenous changes.

Table 2. Assumed Boundary Conditions and Major Kesults for Residential Energy Use Forecasts

\begin{tabular}{|c|c|c|c|c|c|c|c|c|c|c|}
\hline \multirow{3}{*}{$\begin{array}{c}\text { Case } \\
\text { No. }\end{array}$} & \multirow{3}{*}{$\begin{array}{l}\text { Household } \\
\text { formation }\end{array}$} & \multirow{3}{*}{$\begin{array}{l}\text { Housing } \\
\text { choices }\end{array}$} & \multirow{3}{*}{$\begin{array}{c}\text { Per } \\
\text { capita } \\
\text { income }\end{array}$} & \multirow{3}{*}{$\begin{array}{c}\text { Fuel } \\
\text { prices }\end{array}$} & \multirow{3}{*}{\multicolumn{2}{|c|}{$\begin{array}{c}\text { Toproved } \\
\text { efficiency of } \\
\text { new equipment }\end{array}$}} & \multirow{2}{*}{\multicolumn{2}{|c|}{$\begin{array}{l}\text { Increased thermal } \\
\text { integrity of } \\
\text { strurtures: }\end{array}$}} & \multicolumn{2}{|c|}{ Energy use } \\
\hline & & & & & & & & & \multirow{2}{*}{$\frac{2000}{\left(10^{18}\right.}$} & \multirow{2}{*}{$\begin{array}{l}\text { 1975-2000 } \\
\text { joules) }\end{array}$} \\
\hline & & & & & & & New & Existing & & \\
\hline 1 & Series A & 1970 & $2.8 \% / y r$ & Constant & & No & No & No & 32.7 & 650 \\
\hline 2 & Series C & 1970 & & & & & & & 30.3 & 611 \\
\hline 3 & Series A & $1960-70$ & & & & & & & 31.7 & 636 \\
\hline 4 & Series C & & $2.8 \% / \mathrm{yr}$ & & & & & & 29.4 & 604 \\
\hline 5 & & & $2.1 \% / \mathrm{yr}$ & Constant & & & & & 28.4 & 595 \\
\hline 6 & & & & Low growth & & & & & 25.2 & 563 \\
\hline 7 & & & & High growth & & No. & & & 24.1 & 543 \\
\hline 8 & & & & & Yes: & to 1980 & & & 21.6 & 507 \\
\hline 9 & & & & & Yes: & to 2000 & No & & 20.1 & 494 \\
\hline 10 & & & & & & No & Yes & No & 23.4 & 533 \\
\hline 11 & & & & & & No & No & Yes & 23.9 & 535 \\
\hline 12 & Series C & $1960-70$ & $2.1 \% / \mathrm{yr}$ & High growth & Yes: & to 2000 & Yes & Yes & 19.3 & 478 \\
\hline
\end{tabular}




\section{HIGH FORECAST}

The starting point for our exploration of alternative forecasts is. a set of assumptions that yields a high growth in energy use to the year 2000. We assume that household formation will occur according to the Bureau of the Census series A (high) forecast, ${ }^{5}$ shown in Fig. 3.

We assume that the distribution of housing choices (single-family, 'multi-family, trailers) by age of household head remains constant at the 1970 distribution, 6 also shown in Fig. 3: $69 \%$ single-family, $28 \%$ multifamily, $3 \%$ trailer. Real per capita income is assumed to grow at an average annual rate of $2.8 \%$ between 1975 and 2000 . Residential fuel prices are held constant at their 1975 values. Finally, no improvements in technical efficiency of new residential equipment or thermal integrity of residential structures are postulated.

Figure 4 shows forecasts of electricity, gas, oil and total household fuel use produced by our simulation model (run 1) using the inputs

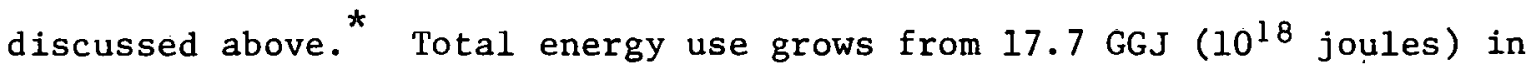
1975 to 32.7 GGJ in 2000, with an average annual growth rate of $2.5 \%$. Electricity use grows more rapidly at $3.8 \%$ /year, while gas and oil grow more slowly at $1.8 \%$ and $0.4 \%$, respectively. ${ }^{\dagger}$ Because of differences in growth rates, the percentage of fuel provided by electricity grows from $43 \%$ in 1975 to $59 \%$ in 2000 . Comparable figures for gas are $34 \%$ and $29 \%$, for oil $19 \%$ and $11 \%$, and for other fuels $4 \%$ and $1 \%$.

\footnotetext{
* The low forecast shown in Fig. 4 (run 12) is discussed later.

† Our energy demand model assumes implicitly that energy supplies are always available at the exogeneously-specified prices.
} 


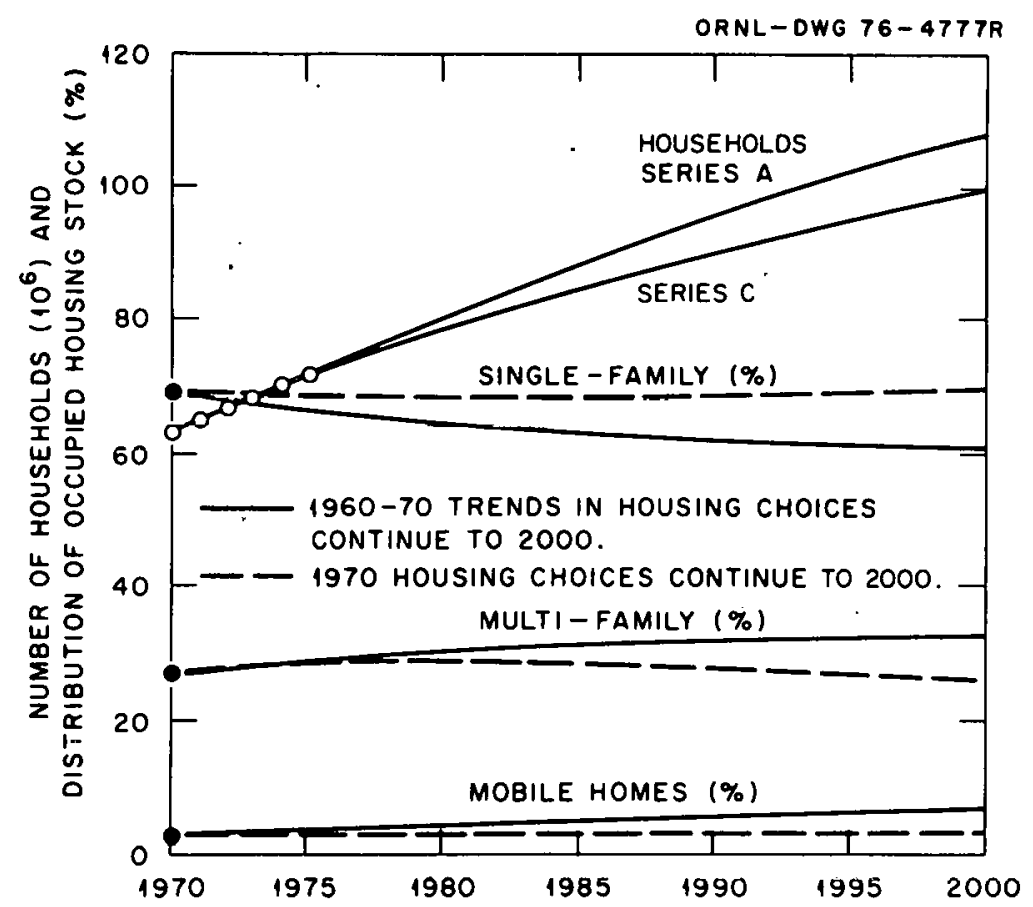

Fig. 3. Forecasts of households and occupied housing stock: 1970-2000.

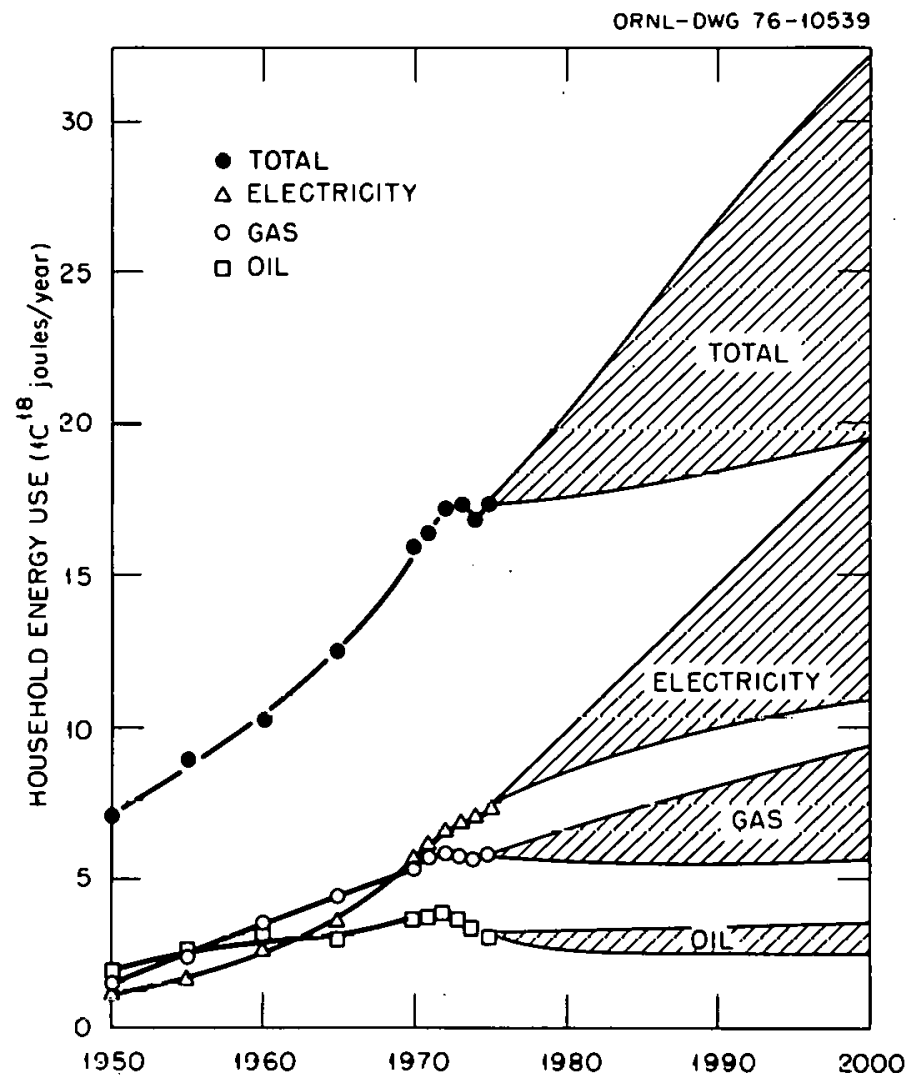

Fig. 4. Residential energy use and forecasts: 1950-2000. 
The distribution of fuel by end use changes slightly over time: the percentages of total fuel used for space heating and water heating decline slightly, while the percentage used for air conditioning grows from $7 \%$ in 1975 to $11 \%$ in 2000 .

The model shows a growth in fuel use of $2.5 \% /$ year, compared with the historical rate of $3.6 \%$ /year between 1950 and 1975 . Table 3 shows differences in historical and forecast growth rates for several variables, $1,7,8$ and Fig. 5 shows estimates of the factors that yield lower growth in the forecast period than in the historical period.

Table 3. Comparison of Residential Energy Trends and Determinants

\begin{tabular}{lcc}
\hline & \multicolumn{2}{c}{ Average annual } \\
\cline { 2 - 3 } & $1950-1975$ & $1975-2000$ \\
\hline Population & 1.4 & 1.0 \\
Households & 2.0 & 1.7 \\
Per capita income & 2.3 & 2.8 \\
Tutal Income & $3 . \%$ & 3.8 \\
Electricity & 7.3 & 3.8 \\
Gas & 5.4 & 1.8 \\
Oil & 2.3 & 0.4 \\
Total residential fuel use & 3.6 & 2.5 \\
\hline
\end{tabular}

Changes in household growth account for about one-fourth of the difference in fuel use growth rates.

We assumed that fuel prices remain at their 1975 levels (in constant dollars) to the year 2000. However, between 1950 and the early 1970s, electricity prices declined one-third and gas and oil prices each declined 5\%; see Fig. 2. Overall, household energy prices declined about 15\% between 1950 and the early 1970s. This change in fuel price trends 


$$
\text { ORNL-DWG 76-10538 }
$$
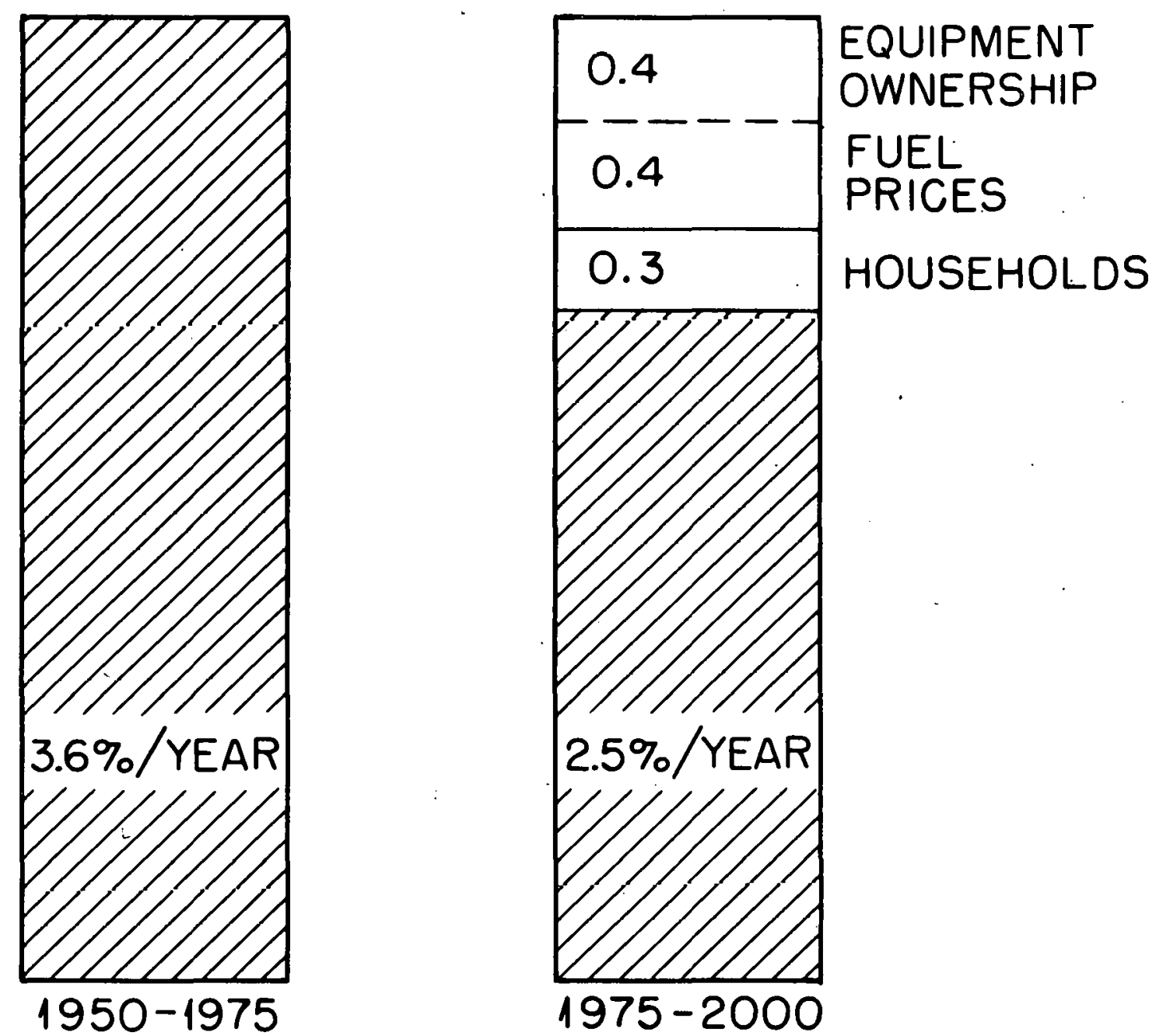

Fig. 5. Comparison of historical and forecast growth rates for residential energy use. 
(from declines to constancy) accounts for roughly one-third of the difference in fuel use growth between the two periods.

Finally, the forecast assumes that no new residential energy uses will be introduced during the next 25 years. However, during the past 25 years, energy use for air conditioning and refrigeration grew dramatically. Growth in air conditioning energy use was primarily due to increasing market penetration: fewer than $1 \%$ of households had air conditioning in 1950 while $50 \%$ had air conditioning in 1974.6 For refrigeration, electricity use grew because of shifts from small manualdefrost units to large automatic-defrost units. ${ }^{9}$ Largely because of these two growth markets, the relative growth of electricity compared with overall household fuel use was higher in the historical period $(2.0 \% /$ year) than in the forecast period $(1.5 \% /$ year $)$. These changes in equipment ownership account for the remainder of the difference between historical and forecast growth rates. *

\section{- DEMOGRAPHIC CHANGES}

Using the forecast discussed above as a reference, we next evaluate the impacts of changes in household growth and housing choices, shown in Fig. 3. Household formation grows at an average annual rate of $1.4 \%$ in the Census series $\mathrm{C}$ forecast, compared with $1.7 \%$ in the series A forecast. 5

\footnotetext{
* This discussion and Fig. 5 imply an accuracy that is unwarranted by either our understanding of historical data or the validity of our model.
} 
Reducing household growth from series A to series C slows energy growth from $2.5 \%$ year to $2.2 \%$ /year, as shown in Table 4 . The reduction in household fuel use in run 2 corresponds exactly with the reduction in household formation. The distributions of energy use by fuel and by end use are unchanged by the change in household growth.

Table 4. Residential Energy Impacts of Demographic Changes

\begin{tabular}{|c|c|c|c|c|c|c|}
\hline \multirow{2}{*}{$\begin{array}{l}\text { Run } \\
\text { No. }\end{array}$} & \multirow[b]{2}{*}{ Description } & \multicolumn{4}{|c|}{ Energy use ( $10^{18}$ joules) } & \multirow{2}{*}{$\begin{array}{c}\text { Average } \\
\text { annual } \\
\text { growth } \\
\text { rate }(\%)\end{array}$} \\
\hline & & 1980 & 1990 & 2000 & $\begin{array}{l}\text { Cumulative } \\
1975-2000\end{array}$ & \\
\hline 1 & $\begin{array}{l}\text { Series A, } 1970 \text { housing } \\
\text { choices }\end{array}$ & 20.16 & 26.67 & 32.69 & 649.6 & $2.48 \%$ \\
\hline \multirow[t]{2}{*}{2} & $\begin{array}{l}\text { Series C, } 1970 \text { housing } \\
\text { choices }\end{array}$ & 19.72 & 25.01 & 30.28 & 617.4 & $2.18 \%$ \\
\hline & Savings re $\# 1$ & $2.2 \%$ & $6.2 \%$ & $7.4 \%$ & $5.0 \%$ & \\
\hline \multirow[t]{2}{*}{3} & Series A, $60-70$ trends & 19.94 & 26.03 & 31.69 & 635.8 & $2.37 \%$ \\
\hline & Savings re '非 & $1.1 \%$ & $2.4 \%$ & $3.1 \%$ & $2.1 \%$ & \\
\hline 4 & $\begin{array}{l}\text { Series C, } 60-70 \text { trends } \\
\text { Savings re 非 } 1\end{array}$ & $\begin{array}{r}19.50 \\
3.3 \%\end{array}$ & $\begin{array}{r}24.42 \\
8.4 \%\end{array}$ & $\begin{array}{l}29.35 \\
10.2 \%\end{array}$ & $\begin{array}{r}604.4 \\
7.0 \%\end{array}$ & $2.07 \%$ \\
\hline
\end{tabular}

In the high forecast ( $r$ un 1 ) wè assumed that housing choices as functions of age of household head would remain constant at their 1970 values. In run 3 we assume that housing choices change along an extrapolation of the 1960-1970 trends. ${ }^{6}$ The consequent distribution of households by housing type is shown in Fig. 3: the percentage of households in single-family units in 2000 declines from $69 \%$ in run 1 to $61 \%$ in run 3 .

Table 4 shows how the energy impacts of the shift in housing choice increase over time, growing to $3 \%$ of the run 1 fuel use in 2000 . The 
distribution of energy by fuel is essentially the same in run 3 as in run 1. However, there is a change in the distribution by end use. The shift to multi-family and trailer housing, with their smaller space heating and cooling demands per unit, reduces energy use for these two functions. In the year 2000, energy uses for space heating and air conditioning are 5\% less in run 3 than in run 1 . Energy for all other end uses is unchanged.

Table 4 also shows the energy impacts of changing both household growth and housing choices. In run 4 household formation grows according to the series $\mathrm{C}$ forecast and housing choices occur along the extrapolation of 1960-1970 trends. Energy savings grow from $3 \%$ in 1980 to $10 \%$ in 2000 .

\section{INCOME CHANGES}

The four runs discussed so far assume growth in real per capita income from 1975 through 2000 of 2.8\%/year. This yields an increase in total income (population $\times$ per capita income) consistent with historical growth (Table 3).

However, some economic forecasts suggest a slower growth in income for the coming decades. For example, a recent Data Resources macroeconomic forecast ${ }^{10}$ has a growth in per capita income of $2.1 \% /$ year between 1974 and 1990 .

To evaluate the impacts on energy use of slower growth in income, we use run 4 as a reference and reduce per capita income growth from 2.8 to $2.1 \% /$ year. This reduces per capita income in 2000 from $\$ 11,600$ to 
$\$ 9,800$; both considerably higher than the 1975 level of $\$ 5,800 .^{*}$ Growth in energy use is reduced from 2.1 to $1.9 \% /$ year (Table 5). The energy savings due to slower income growth increase from $0.5 \%$ in 1980 to $3.1 \%$ in 2000 .

Table 5. Residential Energy Impacts of Income Changes

\begin{tabular}{|c|c|c|c|c|c|c|}
\hline \multirow{2}{*}{$\begin{array}{l}\text { Run } \\
\text { No. }\end{array}$} & \multirow{2}{*}{ Description } & \multicolumn{4}{|c|}{ Energy use ( $10^{18}$ joules) } & \multirow{2}{*}{$\begin{array}{c}\text { Average } \\
\text { annual } \\
\text { growth } \\
\text { rate }(\%)\end{array}$} \\
\hline & & 1980 & 1990 & 2000 & $\begin{array}{l}\text { Cumulative } \\
1975-2000\end{array}$ & \\
\hline 4 & $\begin{aligned} \text { Series } C, & 60-70 \\
\text { trends, } & 2.8 \% / \mathrm{yr}\end{aligned}$ & 19.50 & 24.42 & 29.35 & 604.4 & $2.07 \%$ \\
\hline \multirow[t]{2}{*}{5} & $2.1 \% / \mathrm{yr}$ & 19.41 & 24.00 & 28.43 & 594.9 & $1.94 \%$ \\
\hline & Savings re $\# 4$ & $0.5 \%$ & $1.7 \%$ & $3.1 \%$ & $1.6 \%$ & \\
\hline
\end{tabular}

The present version of our model underestimates the energy impacts of income changes because it. allows only for changes in equipment usage, but not equipment ownership, in response to income changes. Thus the changes in energy use described above should be considered lower bounds on the effects of income changes on energy use. This underestimation occurs because we assume that income elasticities are the same for all fuels and end uses. While this is surely incorrect, we were unable to

* These income figures are given in terms of 1975-\$. 
find consistent and reliable estimates for these income elasticities. * Because of this assumed uniformity of elasticities, changes in income do not induce shifts in fuel choice.

\section{FUEL PRICE CHANGES}

The changes considered so far - in household formation, housing choices, and income growth - are generally not considered part of the nation's energy policy deliberations. The following discussions, and the computer results on which they are based, deal with energy policies and programs of FEA, ERDA, and the Congress.

One powerful tool for slowing energy growth is to increase fuel prices. Proponents argue that prices are now too low because they do not include various social costs associated with energy extraction, production, and use: adverse environmental impacts such as air pollution from power plants and refineries, cxtreme reliance on foreign nations for energy imports, inter-generational considerations (e.g., energy scarcities), etc. Proponents also feel that energy taxes are easy to administer, effective, and relatively benign because they allow consumers maximum choice in terms of equipment ownership and use.

Opponents argue that the economic burden of higher energy prices on low-income families would be excessive, that demand for energy is

\footnotetext{
*A forthcoming ORNL report ${ }^{11}$ describes cross-section models we constructed for space heating, water heating, cooking, air conditioning, and food freezing that do include estimates of income elasticities. These new models are presently being incorporated into our overall simulation model.
} 
relatively insensitive to price changes, and that economic growth would be adversely affected by higher energy prices.

We examined fuel price projectons from a number of sources and ultimately selected two sets of trajectories produced by Anderson's energy supply-demand model; ${ }^{12}$ see Fig. 6 . The low price series yields prices in the year 2000 that are nearly $50 \%$ higher for electricity and gas and 10\% higher for oil than 1975 prices. The high price series yields prices in 2000 that are about $60 \%$ higher for electricity and gas and $35 \%$ higher for oil than 1975 prices.*

Households can respond to fuel price increases in three ways. Initially they can change the manner in which they operate existing stocks of equipment and structures (e.g., lower thermostats in winter). When equipment wears out, they can switch fuels (e.g., replace an electric water heater with a gas water heater), choose a more efficient unit (e.g., replace an inefficient air conditioner with a more efficient one), or both.

The present version of our residential energy model properly evaluates the first two types of responses to fuel price increases: . usage changes and fuel switching. However, the model cannot endogenously estimate. changes in equipment efficiencies; these efficiencies, must be

\footnotetext{
* It is not clear whether Anderson's fuel price projections assume natural gas deregulation and/or oil price decontrol. However, his gas and oil prices are much lower than those produced by the Brookhaven National Laboratory energy system optimization model or the FEA PIES model. Using either the FEA or BNL price trajectories would yield lower energy growth and greater shifts from oil and gas to electricity. Also, Fig. 6 shows that differences between Anderson's two price trajectories are minor - roughly a $15 \%$ difference in the year 2000 .
} 


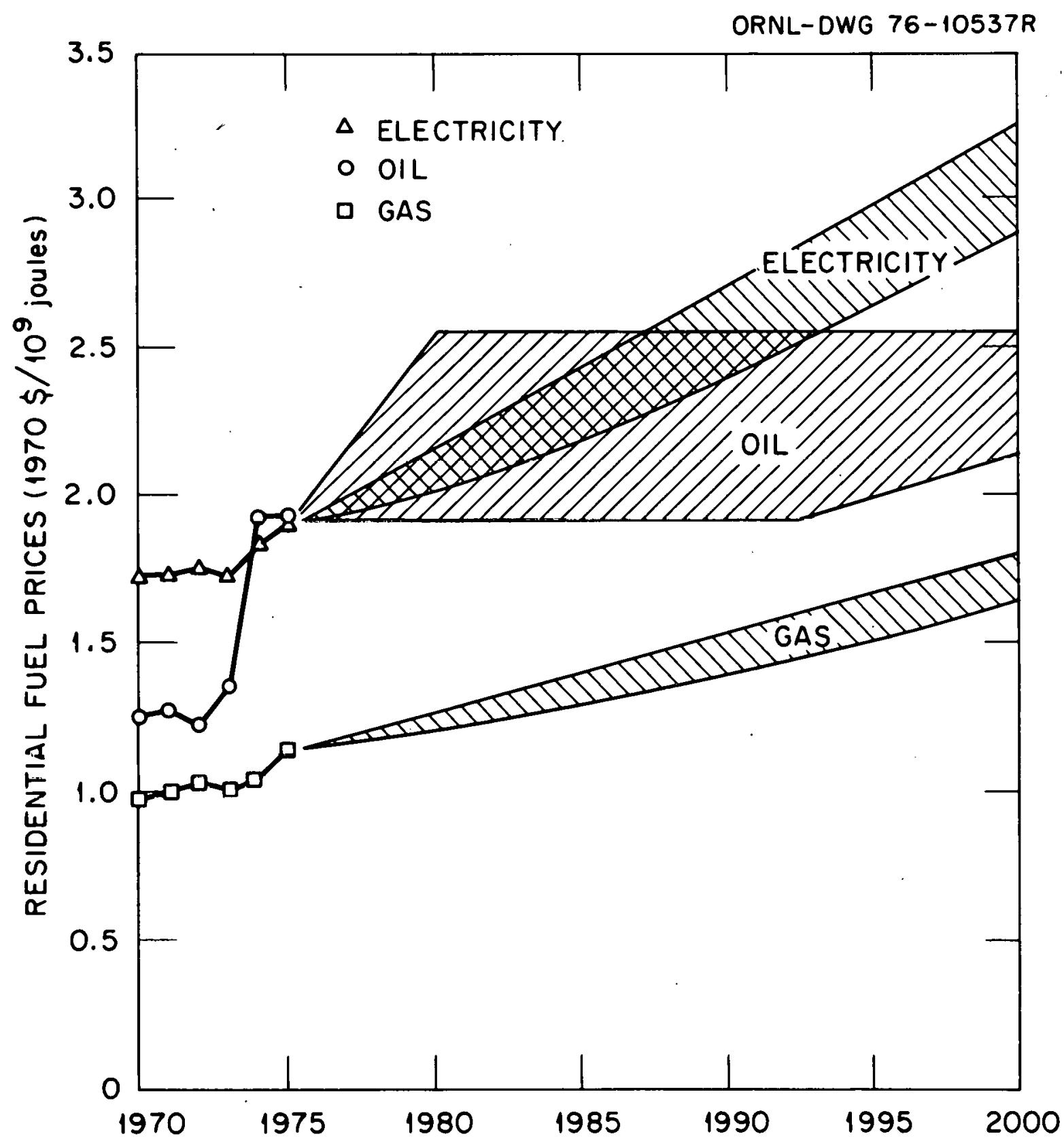

Fig. 6. Assumed fuel price trajectories to 2000. 
exogenously specified. Because of this limitation, the energy saving impacts of fuel price increases are understated.

The impacts of Increasing fuel prices from their constant 1975 values (run 5) to Anderson's low price series (run 6) and Anderson's high price series (run 7) are shown in Table 6. If prices increase according to Anderson's low price trajectories, residential energy use in the year 2000 would be $11 \%$ less than otherwise. Increasing prices still further to the high price series would reduce energy use an additional $4 \%$.

Table 6. Residential Energy Impacts of Fuel Price Changes

\begin{tabular}{|c|c|c|c|c|c|c|}
\hline \multirow{2}{*}{$\begin{array}{l}\text { Run } \\
\text { No. }\end{array}$} & \multirow[b]{2}{*}{ Description } & \multicolumn{4}{|c|}{ Energy use $\left(10^{18}\right.$ joules $)$} & \multirow{2}{*}{$\begin{array}{r}\text { Average } \\
\text { annual } \\
\text { growth } \\
\text { rate }(\%)\end{array}$} \\
\hline & & 1980 & 1990 & 2000 & $\begin{array}{l}\text { Cumulative } \\
1975-2000\end{array}$ & \\
\hline 5 & Constant prices & 19.41 & 24.00 & 28.43 & 594.9 & $1.94 \%$ \\
\hline \multirow[t]{2}{*}{6} & Low growth & 19.21 & 22.61 & .25 .22 & 562.9 & $1.45 \%$ \\
\hline & Savings re $\# 5$ & $1.0 \%$ & $5.8 \%$ & $11.3 \%$ & $5.4 \%$ & \\
\hline \multirow[t]{2}{*}{7} & High growth & 18.64 & 21.66 & 24.11 & 542.6 & $1.27 \%$ \\
\hline & Savings re $\# 5$ & $4.0 \%$ & $9.8 \%$ & $15.2 \%$ & $8.8 \%$ & \\
\hline
\end{tabular}

Because the changes in fuel prices and assumed elasticities differ from one fuel to another, the price increases change the distribution of energy use by fuel. Electricity's share of the total grows more slowly with Anderson's fuel prices than with constant prices; the shares accounted for by gas and oil decline more slowly with Anderson prices. Distributions for the year 2000 are compared with the actual 1975 distribution below: 


\begin{tabular}{lcccc}
\hline & & \multicolumn{3}{c}{$\begin{array}{c}\text { Fuel use } \\
\text { distribution in 2000 } \\
\text { in run number: }\end{array}$} \\
\cline { 3 - 5 } & 1975 & 5 & 6 & 7 \\
\hline Electricity & $43 \%$ & $60 \%$ & $56 \%$ & $56 \%$ \\
Gas & 34 & 28 & 29 & 30 \\
Oi1 & 19 & 11 & 14 & 13 \\
Other & 4 & 1 & 1 & 1 \\
\hline
\end{tabular}

TECHNOLOGICAL CHANGES

\section{Equipment Efficiency Improvements}

As part of its responsibilities under the Energy Policy and Conservation act, ${ }^{3}$ FEA is administering the federal appliance efficiency program. FEA's initial targets for improvements in appliance energy efficiency form the basis for the values shown in Table 7.13 In addition to the 1980 targets, we show continued improvements in appliance and equipment performance to the year 2000. New equipment efficiencies are higher in 1980 , on average, by about $25 \%$ relative to $1970-75$ values. In the year 2000, the average efficiency increase is about $40 \%$.

As an example of the changes required to meet such standards, consider residential water heaters. The table below shows the impacts on annual energy use due to factory reduction in thermostat setting, increase in insulation thickness on the heater jacket, and reduction in pilot light size for gas water heaters: 14 


\begin{tabular}{|c|c|c|}
\hline \multirow[t]{2}{*}{ ' } & \multicolumn{2}{|c|}{$\begin{array}{l}\text { Percent reduction in annual } \\
\text { energy requirement }\end{array}$} \\
\hline & Electric & Gas \\
\hline $\begin{array}{l}\text { Reduce thermostat setting } \\
\text { by } 11^{\circ} \mathrm{C} \\
\text { plus }\end{array}$ & $16 \%$ & $15 \%$ \\
\hline $\begin{array}{c}\text { Add } 5 \mathrm{~cm} \text { of extra } \\
\text { insulation to jacket } \\
\text { plus }\end{array}$ & $6 \%$ & $13 \%$ \\
\hline $\begin{array}{l}\text { Reduce size of pilot light } \\
\text { from } 790 \text { to } 370 \mathrm{~kJ} / \mathrm{hr}\end{array}$ & -- & $8 \%$ \\
\hline $\begin{array}{l}\text { Total reduction in energy } \\
\text { use }\end{array}$ & $22 \%$ & $36 \%$ \\
\hline
\end{tabular}

The schedule of efficiency changes in Table 7 requires gas and electric water heaters to meet the performance achieved by the changes shown above some time during the 1990s. Similar exercises could be carried out for each fuel/end use combination to evaluate the design changes that might be used to meet the goals of Table $7 . *$

A comparison of runs 8 and 7 (Table 8 ) shows the impacts of improving appliance and equipment efficiencies between 1976 and 1980 and then holding efficiencies at their 1980 levels to the year 2000. A comparison of runs 9 and 7 shows the impacts of continuing to improve

\footnotetext{
* The efficiency changes evaluated here and shown in Table 7 generally have cost, as well as, energy efficiency, impacts. Design changes in equipment, appliances, and structures to improve energy efficiency will generally increase capital costs. These cost impacts are not evaluated here because the present version of our energy model cannot deal explicitly with capital costs. We assume, implicitly, that the equipment efficiency and thermal performance standards evaluated in this report are cost-effective. We are completing development of an improved version of the ORNL residential energy use simulation model that is explicitly sensitive to both operating (fuel) and capital costs.
} 
Table 7. Assumed Improvements in Energy Requirements for New Equipment and Thermal Loads for New Structures

$$
(1970=1.0)
$$

\begin{tabular}{|c|c|c|c|c|}
\hline & 1975 & 1980 & 1990 & 2000 \\
\hline \multicolumn{5}{|l|}{ Space heating equipment } \\
\hline Electric & 1.0 & 0.95 & 0.90 & 0.85 \\
\hline Gas & 1.0 & 0.80 & 0.70 & 0.65 \\
\hline $0 i 1$ & 1.0 & 0.80 & 0.70 & 0.65 \\
\hline \multicolumn{5}{|l|}{ Water heating equipment } \\
\hline Electric & 1.0 & 0.89 & 0.80 & 0.75 \\
\hline Gas & 1.0 & 0.74 & 0.66 & 0.60 \\
\hline 011 & 1.0 & 0.74 & 0.66 & 0.60 \\
\hline Refrigerators & 1.0 & 0.68 & 0.60 & 0.50 \\
\hline \multicolumn{5}{|l|}{ Cooking equipment } \\
\hline Electric & 1.0 & 0.83 & 0.75 & 0.70 \\
\hline Gas & 1.0 & 0.67 & 0.60 & 0.50 \\
\hline Air conditioning equipment & 1.0 & 0.80 & 0.70 & 0.65 \\
\hline Other equipment & 1.0 & 0.90 & 0.80 & 0.75 \\
\hline \multicolumn{5}{|c|}{ 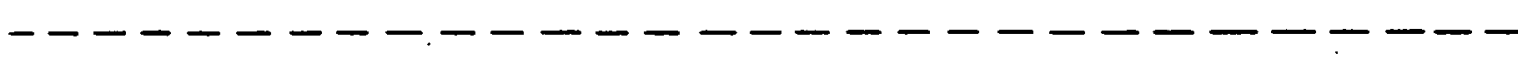 } \\
\hline \multicolumn{5}{|l|}{ Single-family units } \\
\hline Space heating & 1.0 & 0.89 & 0.89 & 0.89 \\
\hline Air conditioning & 1.0 & 0.70 & 0.70 & 0.70 \\
\hline \multicolumn{5}{|l|}{ Apartments } \\
\hline Space heating & 1.0 & 0.54 & 0.54 & 0.54 \\
\hline Air conditioning & 1.0 & 0.45 & 0.45 & 0.45 \\
\hline \multicolumn{5}{|l|}{ Trailers } \\
\hline Space heating & 1.0 & 1.0 & 1.0 & 1.0 \\
\hline Air conditioning & 1.0 & 1.0 & 1.0 & 1.0 \\
\hline
\end{tabular}

Sources: refs. 13, 14, and author's assumptions for space heating equipment. 
efficiencies beyond 1980. The energy savings with either schedule of efficiency improvements are considerable: $10 \%$ and $17 \%$ in the year 2000 . Continued improvement in equipment efficiencies beyond 1980 yields significant energy savings by the year 2000. The cumulative energy savings between 1975 and 2000 is increased by a third (to 49 GGJ) in going from run 8 to run 9 .

Table 8. Residentlal Energy Impacts of Equipment Efficiency and Thermal Integrity Improvements

\begin{tabular}{|c|c|c|c|c|c|c|}
\hline \multirow{2}{*}{$\begin{array}{l}\text { Run } \\
\text { Nó. }\end{array}$} & \multirow{2}{*}{ Description } & \multicolumn{4}{|c|}{ Energy use ( $10^{18}$ joules) } & \multirow{2}{*}{$\begin{array}{l}\text { Average } \\
\text { annual } \\
\text { growth } \\
\text { rate (\%) }\end{array}$} \\
\hline & & 1980 & 1990 & 2000 & $\begin{array}{l}\text { Cumulativo } \\
\text { 1975-2000 }\end{array}$ & \\
\hline 7 & No efficiency changes & 18.64 & 21.66 & 24.11 & 542.6 & $1.27 \%$ \\
\hline 8 & $\begin{array}{l}\text { Efficiency increases } \\
\text { to } 1980 \\
\text { Savings re } \# 7\end{array}$ & $\begin{array}{r}18.07 \\
3.1 \%\end{array}$ & $\begin{array}{r}19.92 \\
8.0 \%\end{array}$ & $\begin{array}{l}21.60 \\
10.4 \%\end{array}$ & $\begin{array}{r}506.6 \\
6.6 \%\end{array}$ & $0.82 \%$ \\
\hline 9 & $\begin{array}{l}\text { Efflciency increases } \\
\text { to } 2000 \\
\text { Savings re } \# 7\end{array}$ & $\begin{array}{r}18.07 \\
3.1 \%\end{array}$ & $\begin{array}{l}19.42 \\
10.3 \%\end{array}$ & $\begin{array}{l}20.12 \\
16.5 \%\end{array}$ & $\begin{array}{r}494.1 \\
8.9 \%\end{array}$ & $0.54 \%$ \\
\hline 10 & $\begin{array}{l}\text { New construction } \\
\text { standards } \\
\text { Savings re } \# 7\end{array}$ & $\begin{array}{r}18.49 \\
0.8 \%\end{array}$ & $\begin{array}{r}21.20 \\
2.1 \%\end{array}$ & $\begin{array}{r}23.39 \\
3.0 \%\end{array}$ & $\begin{array}{r}532.8 \\
1.8 \%\end{array}$ & $1.15 \%$ \\
\hline 11 & $\begin{array}{l}\text { Retrofit program, } \\
\text { 1976-1985 } \\
\text { Savings re } \# 7\end{array}$ & $\begin{array}{r}18.32 \\
1.8 \%\end{array}$ & $\begin{array}{r}21.32 \\
1.6 \%\end{array}$ & $\begin{array}{r}23.86 \\
1.0 \%\end{array}$ & $\begin{array}{r}534.9 \\
1.4 \%\end{array}$ & $1.23 \%$ \\
\hline 12 & $\begin{array}{l}\text { Equipment improvements } \\
\text { to } 2000 \text {, new con- } \\
\text { struction standards, } \\
\text { retrofit program } \\
\text { Savings re \#7 }\end{array}$ & $\begin{array}{r}17.60 \\
5.6 \%\end{array}$ & $\begin{array}{l}18.71 \\
13.6 \%\end{array}$ & $\begin{array}{l}19.31 \\
19.9 \%\end{array}$ & $\begin{array}{l}478.0 \\
11.9 \%\end{array}$ & $0.38 \%$ \\
\hline
\end{tabular}

The distribution of residential energy by fuel type does not change at all in response to these efficiency improvements. This is surprising because the improvements shown in Table 7 are greater for gas and oil equipment than for electric equipment; thus one would expect the savings in gas and oil to be relatively larger than those for electricity. However, because the operating costs of new gas and oil units are 
reduced, the model forecasts some fuel switching. That is, some households that formerly used electricity for a particular end use, will shift to gas and oil because of the efficiency improvements. Thus, some of the gas and oil savings are lost because of fuel switching.

Also, household usage of fuels will increase because energy efficiency of new equipment increases (and operating costs decline). For example, households with efficient water heaters will take longer showers than they otherwise would. These usage changes are greater with gas and oil equipment than with electric equipment because of the greater efficiency' improvements for gas and oil units.

Thermal Integrity Improvements

As noted earlier, ASHRAE recently developed a set of thermal standards for design of new residential and commercial structures. ${ }^{4}$ An evaluation of these standards by the A. D. Little Company ${ }^{4}$ showed that space heating energy requirements for new single-family units would be reduced 11\% nationwide, compared with typical 1973 construction practices. Comparable savings for low-rise apartment buildings are $46 \%$. Energy savings for air conditioning are $30 \%$ for single-family units and $55 \%$ for apartment buildings. No energy savings were estimated for mobile homes. According to ADL, the increase in cost for tighter construction, additional insulation, and storm windows and doors was almost exactly offset by reduced cost for smaller HVAC equipment. Thus the net impact of these standards on initial cost is negligible.

Space heating energy savings much higher than those estimated with the ASHRAE standards for single-family units can be achieved in a costeffective manner. For example, the Arkansas Power \& Light Energy Saving 
Home Program ${ }^{15}$ shows typical space heating savings relative to conventional construction of $65 \%$ (compared with ADL's estimate of $11 \%$. for the ASHRAE standards). Because the ASHRAE standards are so weak for singlefamily units, the energy saving impacts estimated here are much lower than could be achieved with standards that minimize life-cycle costs rather than maintain initial costs.

In run 10, we assume that the ASHRAE 90-75 standards are fully implemented by 1980 (Table 7) using the unit energy reductions estimated by ADL. The energy impacts of applying these standards to all new single-family and multi-family construction are shown in Table 8. Aggregate energy savings, relative to run 7 , increase from $0.8 \%$ in 1980 to $3.0 \%$ in 2000 . The energy savings are split roughly 50:50 between space heating and air conditioning.

At first glance, these savings are much less than one would expect from a vigorous program to improve thermal integrity of new construction. In part, the national savings are small because of the slight impact on single-family units, which account for half of new residential construction between 1980 and 2000 .

Also, conventional housing units last a long time: typically less than $1 \%$ of the existing stock of occupied housing units is scrapped each year. The inputs on household formation and housing choices used in these runs yield an addition of 17 million single-family and 11 million multi-family units between 1980 and 2000 . Thus, only $28 \%$ of the nation's stock of occupied housing units in the year 2000 is affected by these standards. 
Another reason for the small impact of these standards relates to the end uses affected. Space heating and air conditioning together account for about $65 \%$ of total household fuel use. Combining the effects of long lifetimes for the housing stock and the applicability of the standards to only two end uses shows that more than $80 \%$ of the household energy use in 2000 is completely unaffected by the standards.

A complementary program to adoption of new construction standards is to retrofit existing housing units with additional attic insulation, weatherstripping and caulking, and storm windows and doors. In run 11 we implement a program so that each year from 1976 to $1985,7 \%$ of the remaining ${ }^{*}$ stocks of single-family and multi-family units constructed before 1974 are retrofitted. The improvements due to this program are assumed to be the same as those due to adoption of ASHRAE 90-75 on new units. (The criticism of the ASHRAE standards for single-family units, discussed earlier for new construction, applies here for retrofits: the standards are much weaker than could be applied.)

This retrofit program affects approximately 20 million singlefamily units and 10 million multi-family units during the 1976-1985 decade. In 1985, when the program is terminated, more than a third of the occupied stock of single- and multi-family housing has been affected by the program.

\footnotetext{
${ }^{*}$ The program is applied each year to $7 \%$ of the pre-1974 housing units that have not yet been scrapped and not yet been retrofitted. Thus the pool of eligible housing units declines each year by $8 \%(7 \%+1 \%$ due to scrappage of housing units).
} 
A comparison of the outputs from runs 7 and 11 shows how the energy savings increase while the program is in effect and then slowly decay after the program' is terminated. The energy savings increase from $1.4 \%$ in 1978 to $2.3 \%$ in 1985 , and then decline slowly to $1.0 \%$ in 2000 (Table 8 ). The cumulative energy savings for this program are nearly the same as those for the new construction standards. However, the dynamics of the two programs are quite different. As Table 8 shows, the retrofit program has large savings quickly but the savings decline after the program ends and retrofitted houses are slowly scrapped. Implementation of thermal standards for new construction, on the other hand, yields only small energy savings initially. However, by the year 2000, when a significant fraction of the stock of housing units has been affected by the standards, the energy savings are substantial.

\section{Equipment and Structural Improvements}

Run 12 (Table 8 and Fig. 4) shows the impacts on energy use, relative to run 7, of implementing the equipment efficiency schedule of run 9 , the new construction standards of run 10 , and the retrofit program of run 11. Implementing these three technical improvement programs reduces energy use growth from $1.3 \%$ /year to $0.4 \%$ year. Energy use in the year 2000 is cut by $20 \%$, a savings of $4.8 \mathrm{GGJ}$.

\section{INTERPRETATION OF RESULTS}

Twelve different computer runs were discussed in this report; see Table 2. Growth rates in residential energy use between 1975 and 2000 range from $2.5 \%$ /year (run 1) to $0.4 \% /$ year (run 12 ); cumulative energy 
use for the 1975-2000 period is 650 GGJ in run 1 and 478 GGJ in run 12 . Figure 4 shows forecasts of electricity, gas, and oil use for runs 1 and 12 .

Table 9 shows the influence of the demographic, economic, and technological factors on differences between runs 1 and 12 . The dynamics of residential energy use are such that the fractional energy savings increase over time. Energy use in run 12 is $41 \%$ less in the year 2000 than in run 1; however, the cumulative energy reduction is only $26 \%$. Except for the retrofit standards, each factor listed in Table 9 has a larger energy savings impact in the year 2000 than in earlier years.

Table 9. Contributions to Reduced Residential Energy Use ${ }^{a}$

\begin{tabular}{|c|c|c|}
\hline & \multicolumn{2}{|c|}{ Change in energy use (\%) } \\
\hline & 2000 & $\begin{array}{l}\text { Cumulative } \\
1975-2000\end{array}$ \\
\hline Slower household growth & 15 & 17 \\
\hline Changes in housing choices & 6 & 7 \\
\hline Slower income growth & 6 & 5 \\
\hline Higher fuel prices & 31 & 30 \\
\hline Improved equipment efficiencies & 34 & 30 \\
\hline \multicolumn{3}{|l|}{ Increased thermal integrity: } \\
\hline New structures & 6 & 6 \\
\hline Existing structures & 2 & 5 \\
\hline Overall energy savings $\left(10^{18} \mathrm{~J}\right)$ & 13.4 & 172 \\
\hline \multicolumn{3}{|l|}{ Overall energy savings as $\%$ of } \\
\hline run 1 & $41 \%$ & $26 \%$ \\
\hline
\end{tabular}

Demographic factors (household formation and housing choices) account for $20-25 \%$ of the differences in energy use between runs 1 and 12. Economic factors (incomes and fuel prices) account for $35-40 \%$ of 
the differences. Technical improvements in equipment and structures account for the remaining $40 \%$. Changes in fuel prices and improvements in equipment efficiencies together account for almost two-thirds of the differences.

Table 10 shows the impacts on energy use of the four specific conservation strategies discussed here - higher fuel prices, improvements in efficiencies for new residential equipment, adoption of thermal standards for new construction, and implementation of a retrofit program. The numbers in Table 10 show the contributions of these four factors to the energy reductions in going from run 6 to run 12 .

Table 10. Energy Impacts of Residential Conservation Measures ${ }^{a}$

\begin{tabular}{|c|c|c|}
\hline & \multicolumn{2}{|c|}{ Change in energy use (\%) } \\
\hline & 2000 & $\begin{array}{l}\text { Cumulative } \\
1975-2000\end{array}$ \\
\hline Higher fuel prices & 1.8 & 23 \\
\hline Improved equipment efficiencies & 66 & 57 \\
\hline standards & 12 & 11 \\
\hline Retrofit existing structures & 4 & 9 \\
\hline Overall energy savings $\left(10^{18} \mathrm{~J}\right)$ & 5.9 & .8 .5 \\
\hline $\begin{array}{l}\text { Overall energy savings as \% of } \\
\text { run } 6\end{array}$ & $23 \%$ & $15 \%$ \\
\hline
\end{tabular}

Increasing fuel prices from Anderson's low to his high price series (increases in real prices in 2000 of $10-25 \%$ ) accounts for $20-2.5 \%$ of the decline in fuel use. The dynamics of response to fuel price changes is faster than for the other measures considered; this is shown by the 
larger impact of fuel prices on cumulative energy use than on energy use in the year 2000. This is so because much of the energy use reduction in response to a fuel price increase involves changes in household behavior (usage of existing capital stocks) and is therefore not limited by equipment lifetimes.

The present version of our model cannot evaluate changes in equipment efficiencies or structural thermal integrities induced by higher fuel prices. Therefore, the contribution of higher fuel prices to energy conservation is understated in Table 10; correspondingly the impacts of efficiency standards are overstated.

The improvements in equipment efficiencies shown in Table 7 are responsible for about $2 / 3$ of the energy reduction in 2000 , and for almost $60 \%$ of the cumulative energy savings. Implementation of the ASHRAE 90-75 standards (Table 7) accounts for slightly more than $10 \%$ of the cumulative and year 2000 energy savings. For both new equipment efficiency standards and new construction thermal standards, energy savings increase over time. This is due to the dynamics of capital stock ownership. Improvements in efficiency occur slowly as old equipment and structures are gradually scrapped and replaced with more efficient units.

The dynamics of energy savings due to implementation of the retrofit program (retrofitting 20 million single-family and 10 million multifamily units between 1976 and 1985) are just the opposite. As Table 10 shows, this program produces larger savings in the short-term than in the long-term. Energy savings peak in the early 1980s; after 1985, when 
the program is stopped, the savings gradually decline. Overall, the retrofit program accounts for $5-10 \%$ of the energy reduction.

Together, these four measures reduce energy use in the year 2000 by $23 \%$ and cut cumulative energy use by $15 \%$. Fuel price increases and new equipment efficiency standards account for most of these savings.

\section{CONCLUSIONS}

A comprehensive engineering-economic model of residential energy use developed at ORNL was used to evaluate the energy impacts from 1975 to 2000 of changes in: household formation, housing choices, per capita income, fuel prices, equipment efficiencies, and thermal integrities of new and existing residential buildings. Twelve cases were run with the model to determine the impacts on energy use of each factor, in isolation and in combination with other determinants of fuel use. Major results from these runs are shown in Table 2; details are provided in Tables 4-10. What insights do these computer runs and the consequent mass of numbers provide with respect to future trends in residential energy use? My conclusions aree:*

1. Residential energy use will grow more slowly during the fourth quarter of the 20th Century than it did during the third quarter. 'l'he highest forecast shows a growth of $2.5 \% /$ year, compared with a

\footnotetext{
* In addition to the conclusions concerning residential energy use during the next 25 years, these runs suggest that the ORNL model performs well. Responses of the model to exogenous changes (both individually and in combination) agree with prior expectations; this increases our confidence in results obtained with the model.
} 
growth of $3.6 \%$ /year from $1950-75$ (Fig. 4). Thus, energy use in the year 2000 is almost certain to be less than 33 GGJ, about double the 1975 value of residential energy use. Energy growth will be slower than in the past because of slower growth in population and household formation, changes in fuel price trends, and near saturation of equipment ownership for the major residential energy end uses.*

2. The high forecast discussed apove. is not a likely forecast because it assumes that fuel prices will remain constant at their 1975 values, that household formation and personal income will increase rapidly, and that the 1960-70 trend in housing choices (away from single-family units) will not continue. A more likely forecast is one that assumes slower growth in household formation and incomes, rising fuel prices, and a continuation of the 1960-70 trend in housing choices. Under these "business as usual" assumptions, energy use grows at $1.5 \%$ /year (run 6), reaching a, level of 25 GGJ in 2000, roughly 45\% higher than the 1975 level of residential energy

\footnotetext{
* Because the present version of our model does not adequately account for the possibility of the introduction and adoption of new residential energy end uses, our high forecast may be somewhat low. My judgment suggests that the impact of new end uses will be slight between now and the end of this century.

$t^{T}$ wo deficiencies of the present version of our model should be mentioned. The first, discussed above, concerns the model's imperfect ability to forecast ownership and use of energy-using equipment that performs new residential functions. The second is the model's inability to endogenously determine demand for equipment of different efficiencies in response to fuel price changes. The model cannot predict how consumers will respond to fuel price changes in terms of their selection of new equipment with respect to its end-use efficiency. Fortunately, these two factors tend to offset each other.
} 
use. This forecast suggests that energy use will grow at about half its historical rate if no new government programs and policies are implemented. Thus a great deal of energy will be "conserved" because of projected changes in demographic conditions and increases in fuel prices.

3. Implementation of energy conservation programs to raise fuel prices, increase efficiency of new household equipment and improve thermal integrity of both new and existing housing units can have significant energy impacts. A vigorous conservation program (run 12) might yield an average annual growth rate of only $0.4 \%$ between 1975 and 2000, with an energy use in 2000 only 10\% higher than 1975 energy use. Implementation of these programs (run 12) would reduce energy use in 2000 from the business as usual case (run 6) by almost 25\%; . the reduction relative to the high case (run 1) is $40 \%$. These conservation programs assume no lifestyle changes on the part of American households; nor do they assume use of solar energy for any household functions. Thus, energy use in the year 2000 could be kept at the present level with only slight lifestyle changes, modest use of solar energy, additional improvements in efficiencies of equipment and structures, or combinations of the above.

4. Implementation of a program to increase efficiency of residential equipment by 1980 , as specified in the Energy Policy and Conservation Act, can cut energy use in the year 2000 by at least $10 \%$ (run 8 ). However, additional improvements after 1980 yield considerably greater savings. Run 9 assumes that equipment efficiencies continue to improve afler 1980, but at a slower rate; the energy savings in 
the year 2000 in run 9 are $60 \%$ greater than those from run 8 . These results suggest the need for additional research to further improve energy efficiencies of household equipment, and the need for programs to ensure that manufacturers produce and consumers purchase increasingly efficient household equipment.

5. Programs to improve thermal integrity of residential structures can." also provide significant energy savings during the next 25 years. However, the estimated savings (runs 10 and 11) for thermal improvement programs are much less than for programs affecting residential equipment and appliances - only about one-third as great. The energy savings estimated for these ASHRAE-based thermal improvement programs are much less than could be achieved for single-family units. A tough, but economically-efficient, set of thermal standards for new and existing residential units could yield savings comparable to those for the equipment efficiency programs. The different dynamics of retrofit and new construction programs suggest the desirability of implementing both. A combined program would yield short-term savings due to retrofits and long-term savings due to new construction standards.

\section{ACKNOWLEDGMENTS}

I thank David Pilati, Grant Thompson, John Gibbons, Jeffrey Milstein, William Turner, George Murray, Dan Quigley, Paul Craig, Jerry Jackson, William Lin, and Roger Carlsmith for their careful reviews of this report. I appreciate the continuing support and cooperation of Jane Cope, Steven Cohn, William Lin, and Jerry Jackson, who work with me on the development, improvement and use of residential energy models. 


\section{REFERENCES}

1. E. Hirst, W. Lin, and J. Cope, An Engineering-Economic Model of Residential Energy Use, Oak Ridge National Laboratory, ORNL/TM-5470, May 1976.

2. E. Hirst, "Changes in Retail Energy Prices and the Consumer Price Index," Energy, 1(1), March 1976.

3. 94 th Congress, Energy Policy and Conservation Act, PL 94-163, December 22, 1975.

4. American Society of Heating, Refrigerating, and Air-Conditioning Engineers, Energy Conservation in New Building Design, ASHRAE 90-75, 1975; also A. D. Little, Inc., An Impact Assessment of ASHRAE Standard 90-75, Energy Conservation in New Building Design, nerember 1975.

5. Bureau of the Census, "Projections of the Number of Households and Families: 1975 to 1990," Current Population Reports, Series P-25, No. 607, U.S. Department of Commerce, August 1975.

6. Bureau of the Census, 1970 Census of Housing, Detailed Housing Chracteristics, United States Summary, HC(1)-B1, 1972; also 1960 and 1950 Censuses of Housing; also Annual Housing Survey: 1974, General Housing Characteristics for the United States and Regions, Advance Report H-150-74, U.S. Department of Commerce, 1976.

7. Bureau of the Census, Statistical Abstract of the United States 1975, 96 th ed., U.S. Department of Commerce, 1975.

8. Council of Economic Advisors, Economic Report of the President, January 1976.

9. J. Tansil, Residential Consumption of Electricity: 1950-1970, Oak Ridge National Laboratory, Report ORNL/NSF/EP-51, July 1973.

10. Federal Energy Administration, National Energy Outlook, February 1976.

11. W. Lin, E. Hirst, and S. Cohn, Fuel Choices in the Household Sector, Oak Ridge National Laboratory, ORNL/TM-5593, August 1976.

12. K. P. Anderson, A Simulation Analyois of U.S. Energy Demand, Supply, and Prices, Rand Corp., Report R-1591-NSF/EPA, October 1975.

13. Federal Energy Administration, "Proposed FEA Regulations on Energy Efficiency Improvement Targets for Appliances," Federal Register, 41(95), May 14, 1976. 
14. J. P. D'Aclerno, R. J. Bertolami, and E. I. Chao, Energy Consumption in Residential Gas and Electric Water Heaters and Ranges, Oak Ridge National Laboratory, ORNL/MIT-226, February 1976.

15. Owens-Corning Fiberglas Corp., The Arkansas Story, Report No. 1, Energy Conservation Ideas to Build On, March 1976. 
ORNL/CON-2

\section{INTERNAL DISTRIBTUION}

1. S. I. Auerbach

2. S. E. Beall

3. D. J. Bjornstad

4. D. P. Brooks

5. J. R. Buchanan

6. R. S. Carlsmith

7. W. S. Chern

8. S. M. Cohn

9. J. E. Cope

10. F. L. Culler

11. J. G. Delene

12. A. P. Fraas

13. W. Fulkerson

14. G. S. Gill

15. W. R. Griffith

16. M. P. Guthrle

17. N. E. Hardin

18. V. O. Haynes

19-20. E. A. Hirst

21. R. Hoskins

22. J. R. Jackson

23. S. I. Kaplan

24. W. W. Lin

25. R. S. Livingston
26. H. M. Long

27. W. R. Mixon

28. J. W. Miche1

29. J. C. Moyers

30. E. A. Nephew

31. H. Postma

32. M. W. Rosenthal

33. T. H. Row

34. R. L. Spore

35. E. G. Struxness

36. D. B. Trauger

37. G. U. Ulrikson

3R. A. Zinrker

39. Biology Division Laboratory

40-41. Central Research Library

42. Laboratory Records, ORNL R. C. 43-44. Laboratory Records Department

45. ORNL - Y-12 Technical Library Document Reference Section

46. ORNL Patent office

47. Institute for Energy Analys is

48. Research and Technical Support Division, ERDA-ORO

49-208. Energy Conservation Section

\section{EXTERNAL DISTRIBUTION}

209-473. Energy Conservation Distribution

474-500. Technical Information Center, ERDA, P. 0. Box 62, Oak Ridge, TN 37830 